\title{
Threat of blast fishing on coral diversity in Peucang Island, Ujung Kulon National Park, Indonesia
}

\author{
RADEN WILLY WIGUNA GUMBIRA, FITRI RIZKIA, TRI DEWI KUSUMANINGRUM PRIBADI", \\ MUHAMMAD SYAEFUL HIDAYAT \\ Department of Biology, Faculty of Mathematics and Natural Sciences, Universitas Padjadjaran. Jl. Raya-Bandung-Sumedang Km. 21, Jatinangor, \\ Sumedang 45363, West Java, Indonesia. Tel.: +62-22-842 88888, Fax.: +62-22-842 88898, ”email: tridewi.pribadi@ unpad.ac.id
}

Manuscript received: 6 December 2016. Revision accepted: 10 June 2017.

\begin{abstract}
Gumbira RWW, Rizkia F, Pribadi TDK, Hidayat MS. 2017. Threat of blast fishing on coral diversity in Peucang Island National Park, Indonesia. Ocean Life 1: 26-31. As a maritime country with high biodiversity, the health of Indonesian coral reefs is of high concern. Coral reef ecosystems are friable, and mortality occurs relatively quickly after disturbance, not only by nature but also by human activities such as fish bombing. Fish bombing is a big issue that has always threatened coral reefs, including in Peucang Island, part of Ujung Kulon National Park, a place that is protected by law to preserve its natural diversity. A study on coral coverage was conducted to observe the condition of corals and related biota in a coral reef ecosystem. Data was collected using Point Intercept Transect method in $2 \mathrm{~m}$ and $8 \mathrm{~m}$ depths. The results showed that coral coverage in 8 -meter depth is only 44.02 percent of the live coral in 2-meter depth. The reduction in the value of Diversity Indices, Dominance Indices as well as the Evenness Index in all study sites led to low diversity, with no dominance by a particular species at any of the study sites. The results also showed that corals are well distributed in both depths. Over the past three years, the damage to corals in Peucang Island had generally increased by 0.7 percent due to fish bombing activities.
\end{abstract}

Keywords: Blast fishing, coral, diversity, Peucang Island, Ujung Kulon

\section{INTRODUCTION}

Coral reefs are one of the most productive and varied ecosystems on earth and provide many ecosystem services. Coral reefs provide a place for marine life to live, find food, shelter, and breed and also act as the buffer against wave action to prevent erosion and abrasion (Souter and Linden 2000). Coral reefs consist of colonies that became the structure on the ocean floor in the form of deposits of calcium carbonate $\left(\mathrm{CaCO}_{3}\right)$ produced by coral animals and belong to the Phylum Coelenterata (hollow animals) or Cnidaria (Papu 2011).

The coral reef ecosystem is friable, and mortality occurs quickly after disturbance (McCormick and Weaver 2012). Coral growth is influenced by human activities and natural factors, such as nutrient availability, predators, and physicochemical condition of the sea. In certain circumstances, natural conditions will create stable coral reefs. Human factors, such as fish bombing and the use of anchors can damage coral reefs (Papu 2011). Burke et al. (2012), estimated that 60 percent of the world's coral reefs are under immediate threat from human activities due to excessive exploitation of marine resources.

Indonesia is situated within the Coral Triangle Zone that is known to contain the highest marine biodiversity in the world, so it should be maintained and preserved (Burke et al. 2012). The Ujung Kulon National Park Authority, (2009), reported that the water in Ujung Kulon and the surrounding waters of Panaitan are the areas where fishing using explosives takes place quite often which causes damage to coral reefs. The use of bombs in Peucang Island creates destructive shocks in the water, which can virtually destroy the surrounding marine life. Not only due to fish bombing, other fishing activities use environmentally damaging methods as well such as Potassium Cyanide $(\mathrm{KCN})$, trapping on reefs, arad nets, and various other gears that can damage the whole environment and make living coral biota, either soft corals or hard corals, fetched (Ujung Kulon National Park 2011, unpublished data).

Based on this facts, information on coral reefs coverage is expected to reveal the broader impact of the fish bombing that has caused biodiversity degrades on coral reefs ecosystem. For this reason, the study can be used as data to shape policies on coral reefs management in Ujung Kulon National Park.

\section{MATERIALS AND METHODS}

\section{Study sites}

Data was collected in August 2014 at Peucang Island, Ujung Kulon National Park, Banten, Indonesia (102 $02^{\prime} 32$ "-105 $37^{\prime} 37^{\prime \prime}$ E and 06 $30^{\prime} 43$ "- 06² $52^{\prime} 17^{\prime \prime}$ S). Survey dives were conducted at six selected locations to represent the condition of coral reef ecosystems in the Western and Eastern parts of Peucang island. The Western study sites consisted of Bonsai, Handarusa, and Karang Copong while the Eastern sites were Ciapus, Citerjun, and Citerjun 2 (Figure 1). 

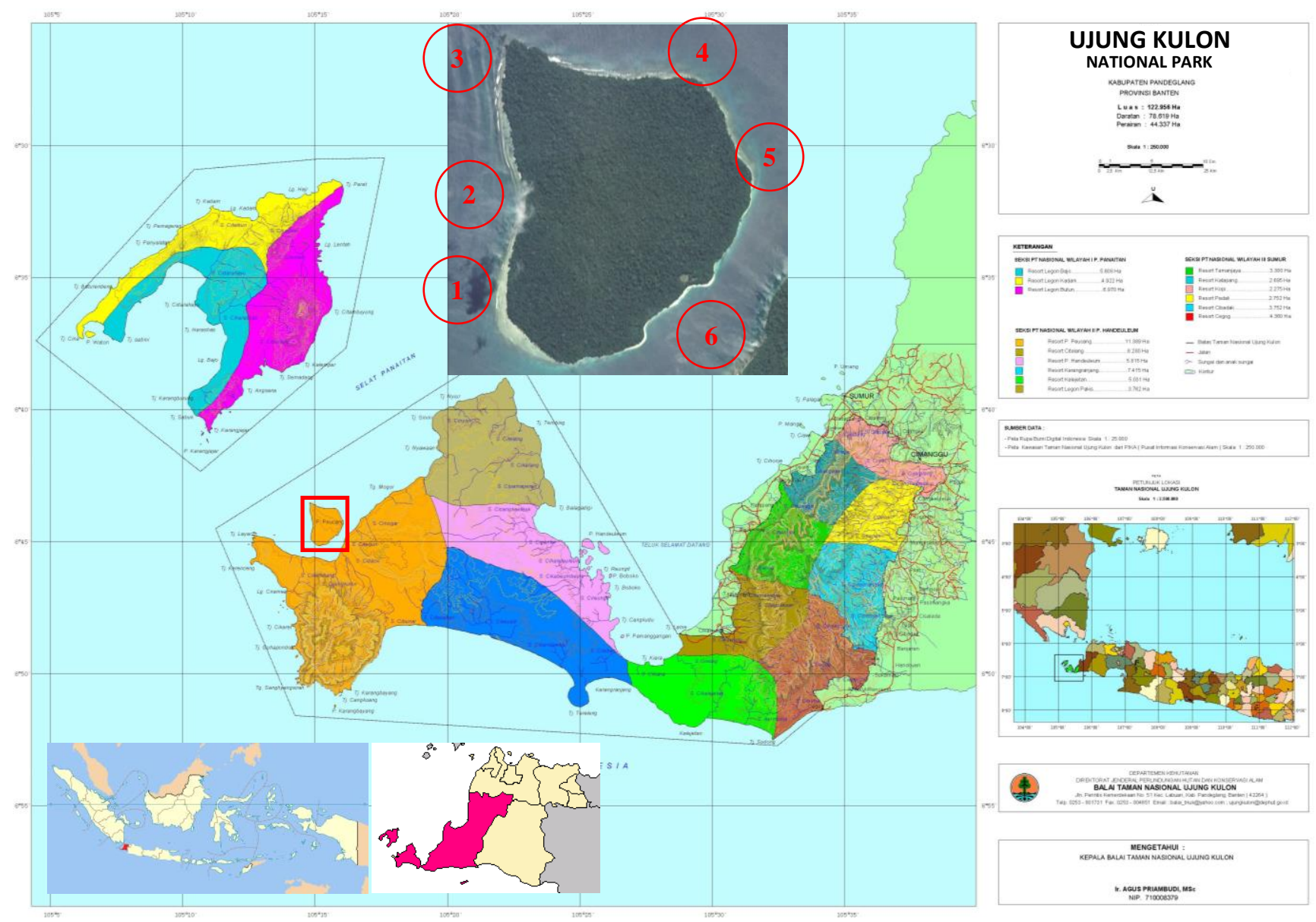

Figure 1. Location of Peucang Island in Ujung Kulon National Park, Pandeglang District, Banten, Indonesia. Spots: 1. Bonsai, 2. Handarusa, 3. Karang Copong, 4. Ciapus, 5. Citerjun, 6. Citerjun 2

\section{Observation on coral reefs}

Point Intercept Transects (PIT) were conducted to investigate the category of life forms (Jokiel et al. 2015). PIT method calculates the percentage cover (\% coverage) of the substrate, using a rope marked at every 0.5 meters or a scale tape (Smart meter roll-out). The distance between transects one, two, and three were 5 meters (Manuputty and Djuwariah 2009). Data were collected from two depths, 2 and 8 meters from the six research sites, using $150 \mathrm{~m}$ transects. Substrate, coral life-form or type of other organism was recorded at $0.5 \mathrm{~m}$ intersects along each transect and calculated into percent coverage for each category. Any additional information such as the description of the location was recorded, especially if there was any obvious damage due to previous bomb fishing.

\section{Data analysis}

The data were arranged in the form of observational tables to be analyzed using this formula (Manuptty and Djuwariah 2009). Hard coral life forms identified comprised of Acropora Branching (ACB), Acropora Submassive (ACS), Acropora Encrusting (ACE), Acropora Tabulate (ACT), Coral Branching (CB), Coral Encrusting
(CE), Coral Foliose, (CF), Coral Heliopora (CHE), Coral Massive (CM), Coral Millepora (CME), Coral Mushroom (CMR), Coral Submassive (CS), and Bleached Coral (BC). Dead coral was recorded as Dead Coral (DC). Other biotas recorded were categorised as Halimeda (HA), Hydroids (HY), Macro algae (MA), Other (OT), Soft Coral (SC), and Xenia (XE), and life forms included abiotic (non-living) were categorised as Rock (RCK), Rubble (RB), and Sand (S) (Piquero et al. 2015).

The condition of coral reef ecosystems was determined by the percent coverage of life hard corals with the criteria that can be seen in Table 1 (Manuputty and Djuwariah 2009).

Table 1. Criteria level of percent coverage life reefs in Peucang Island waters, Ujung Kulon National Park, Banten, Indonesia

\begin{tabular}{cc}
\hline Percentage $(\%)$ & Criteria \\
\hline $0-24.9$ & Broken \\
$25-49.9$ & Moderate \\
$50-74.9$ & Good \\
$75-100$ & Very Good \\
\hline
\end{tabular}


Overview of the continual condition of the community structure of building organisms like coral reefs can clearly be seen from the value of Diversity Indices (H') (Colwell 2008), Evenness Indices (E) (Wilsey and Stirling 2007) and Dominance Indices (C) (Sagar and Sharma 2012). Generally, a stable ecosystem has a high Diversity Indice, as well as Evenness Indices and Dominance Indices which have to remain close to zero (Odum 1971).

\section{RESULTS AND DISCUSSION}

\section{Condition of research area}

In this research, Peucang was divided into two parts of study areas, western and eastern. The western part consists of Bonsai, Handarusa, and Karang Copong while the eastern part Ciapus, Citerjun, and Citerjun 2. Physical parameters of Peucang Island Water can be seen in Table 2.

\section{Reef ecosystem condition}

The observation of coral reef conditions in Peucang Island water can be seen in Figure 2. The highest percentage of hard coral is $61.06 \%$ at a depth of 2 meters while dead coral at a 2-meter depth is around $21.67 \%$. Other organisms, such as macroalgae, soft corals measured in an 8-meter depth had a percentage cover of $39.56 \%$. Abiotic (non-living) elements such as sand, rock, and rubble were found at 8-meter depth with a percentage of $16.67 \%$ (Figure 2).

There is an obvious difference of hard coral coverage between 2-metre and 8-meter depths. The highest hard coral coverage at 2-meter depth was in Karang Copong locations with a percentage of $70.33 \%$, while the lowest was in Bonsai with a percentage of $50.67 \%$. At an 8-meter depth, the highest hard coral coverage was in Citerjun location with a percentage of $33.00 \%$, while the lowest was in Karang Copong with a percentage of $20.33 \%$ (Figure 3 ).

At a 2-meter depth, the hard coral coverage was dominated by life forms like ACB of $21.83 \%$, while there was no trace of $\mathrm{BC}, \mathrm{CHE}, \mathrm{CMR}$. At a 8-meter depth, $8.06 \%$ of the hard coral coverage was dominated by ACB life forms, and the lowest was the $\mathrm{CF}$ with a percentage of $0.42 \%$ (Figure 4).

Dead coral coverage at a 2-meter depth was highest at Bonsai with a percentage cover of $33.67 \%$, while the lowest was at Citerjun 2 with a percentage cover of $8 \%$. At a 8-meter depth, dead coral coverage at Karang Copong was observed to be the highest with a percentage of $34 \%$, while the lowest $8.33 \%$ (Figure 5).

Table 2. Physical parameters of Peucang Island Water, Ujung Kulon National Park, Banten, Indonesia

\begin{tabular}{lcc}
\hline Parameter & \multicolumn{2}{c}{ Depth } \\
\cline { 2 - 3 } Temperature ( $\left.{ }^{\circ} \mathrm{C}\right)$ & 29 & $\mathbf{8 ~ m}$ \\
Brightness $(\mathrm{m})$ & 14 & 29 \\
& \multicolumn{2}{c}{14} \\
GPS Coordinate & $102^{0} 2^{\prime} 32^{\prime \prime}-105^{0} 37^{\prime} 37^{\prime \prime} \mathrm{E}, 06^{0} 30^{\prime} 43^{\prime \prime}-$ \\
\hline
\end{tabular}

Percentage cover of other organisms at a 2-meter depth was highest at Citerjun with a percentage of $19.67 \%$. In contrast, no other organisms were recorded at Coral Copong. At a 8-meter depth, percentage cover of other organisms was highest at Karang Copong with a percentage of $44.67 \%$, while the lowest was found in Citerjun with $31 \%$ (Figure 6). The percentage cover of other organisms is much higher at 8-metre than 2-metre for all sites.

Abiotic coverage at a 2-meter depth had the highest percentage cover $(27.6 \%)$ at Handarusa, but none of these could be found at the location of Citerjun 2. At an 8-meter depth, the highest abiotic coverage was found at Bonsai with a percentage of $24 \%$, while the lowest was in the location of Karang Copong with the percentage of $1 \%$ (Figure 7). Here again, the difference between both depths was obviously noted.

\section{Community structure of coral reefs}

To illustrate the structure of coral reefs communities, necessary analyses of data are required such as Diversity Indices $\left(\mathrm{H}^{\prime}\right)$, Evenness Indices $(\mathrm{E})$ and Dominance Indices (C) on every observation locations. Diversity $\left(\mathrm{H}^{\circ}\right)$, Evenness Indices (E) and Dominance Indices (C) data of the coral reefs are shown in Table 3.

The highest Diversity Index $\left(\mathrm{H}^{\prime}\right)$ value at a depth of 8 meters could be found in Karang Copong, and the lowest in Handarusa. At a depth of 2 meters, the highest value of $\mathrm{H}^{\prime}$ could be found in Ciapus, and the lowest in Citerjun 2. The highest Evenness Index (E) value at a depth of 8 meters was in the Karang Copong, and the lowest in Ciapus. At a depth of 2 meters, the highest value of $E$ could be traced to the Karang Copong, and the lowest in Citerjun. The highest Dominance Index (C) value at a depth of 8 meters could be traced in Handarusa, and the lowest in Karang Copong. At a depth of 2 meters, the highest value of $\mathrm{C}$ was found in Citerjun, and the lowest in Karang Copong (Table 3).

\section{Discussion \\ Environmental conditions}

The same temperature was recorded at Western and Eastern sites, $29{ }^{\circ} \mathrm{C}$. According to Hoey et al. (2016), the temperature affects the speed of metabolism and reproduction of coral. The optimal temperature for coral growth ranges between $23-30^{\circ} \mathrm{C}$, the higher the temperature, the higher the coral animal's metabolism, so that the solubility of oxygen is reduced.

Table 3. Diversity Indices (H'), Evenness Indices (E), and the Dominance Indices (C) of the coral reefs at Peucang Island, Ujung Kulon National Park, Banten, Indonesia

\begin{tabular}{lcccccc}
\hline \multirow{2}{*}{ Locations } & \multicolumn{2}{c}{$\mathbf{H}^{\prime}$} & \multicolumn{2}{c}{ E } & \multicolumn{2}{c}{ C } \\
\cline { 2 - 7 } & $\mathbf{8 ~ m}$ & $\mathbf{2 ~ m}$ & $\mathbf{8 ~ m}$ & $\mathbf{2 ~ m}$ & $\mathbf{8 ~ m}$ & $\mathbf{2 ~ m}$ \\
\hline Bonsai & 1.98 & 1.83 & 0.86 & 0.83 & 0.17 & 0.21 \\
Handarusa & 1.34 & 1.92 & 0.75 & 0.87 & 0.33 & 0.17 \\
Karang Copong & 1.96 & 1.93 & 0.89 & 0.93 & 0.16 & 0.16 \\
Ciapus & 1.44 & 1,97 & 0.69 & 0.86 & 0.31 & 0.19 \\
Citerjun & 1.71 & 1.67 & 0.74 & 0.73 & 0.26 & 0.29 \\
Citerjun 2 & 1.74 & 1.53 & 0.76 & 0.79 & 0.28 & 0.27 \\
\hline
\end{tabular}




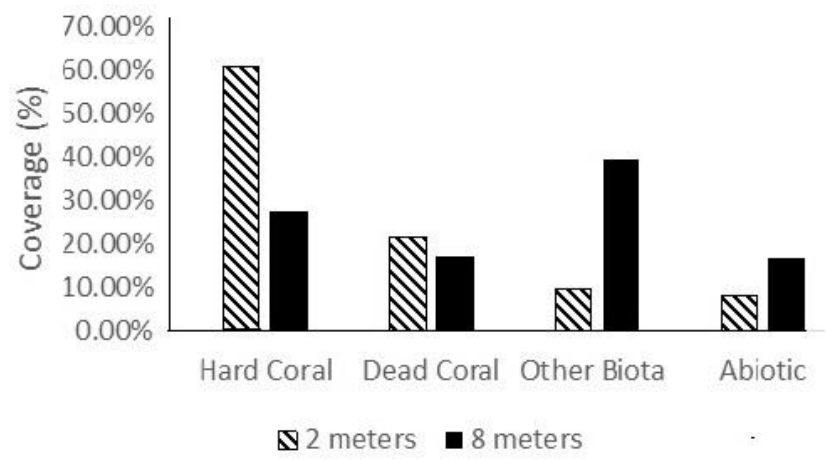

Figure 2. Percentage cover based clustering hard coral, death coral, other biota and abiotic at 2 and 8 meter depths at Peucang Island, Ujung Kulon National Park, Banten, Indonesia

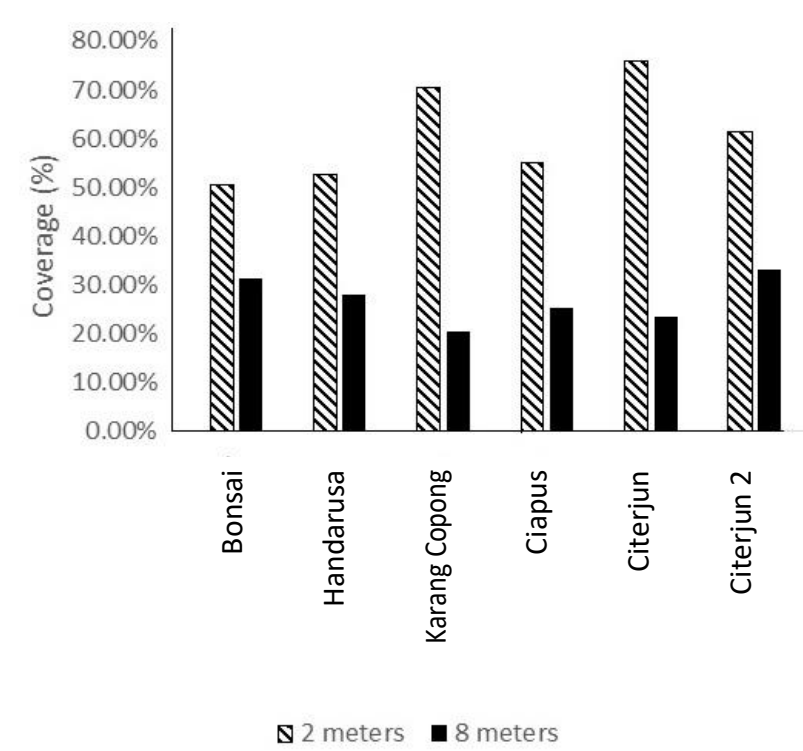

Figure 3. The percentage cover of hard corals at 2 and 8 meters deep at Peucang Island, Ujung Kulon National Park, Banten, Indonesia

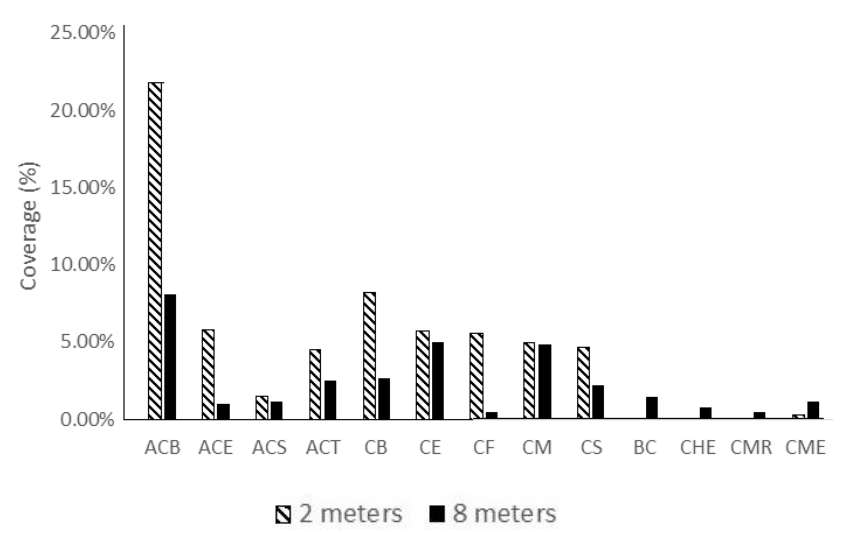

Figure 4. The percentage of hard coral coverage based on life form at 2 and 8 meters deep at Peucang Island, Ujung Kulon National Park, Banten, Indonesia

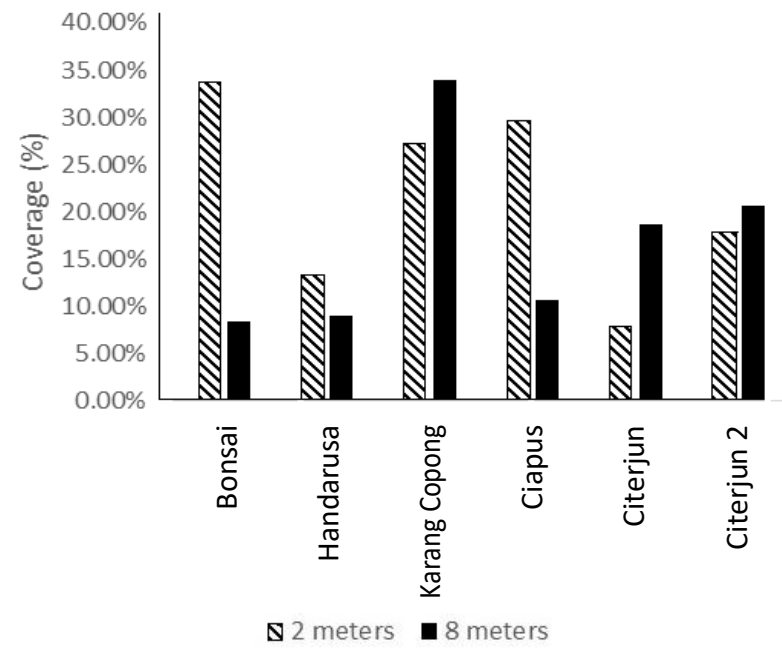

Figure 5. Percentage of dead coral coverage at 2 and 8 meters deep at Peucang Island, Ujung Kulon National Park, Banten, Indonesia

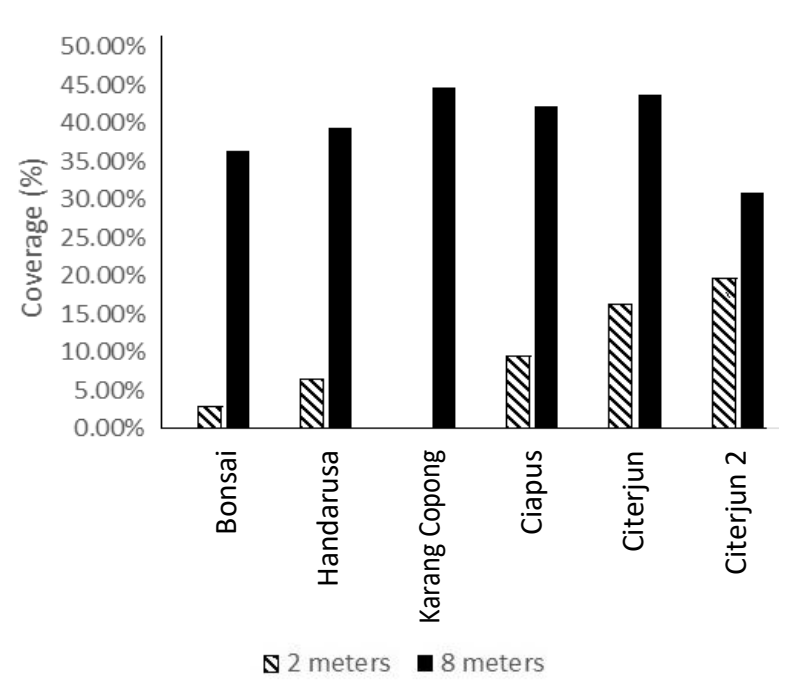

Figure 6. Percentage of other biota coverage at 2 and 8 meters deep at Peucang Island, Ujung Kulon National Park, Banten, Indonesia

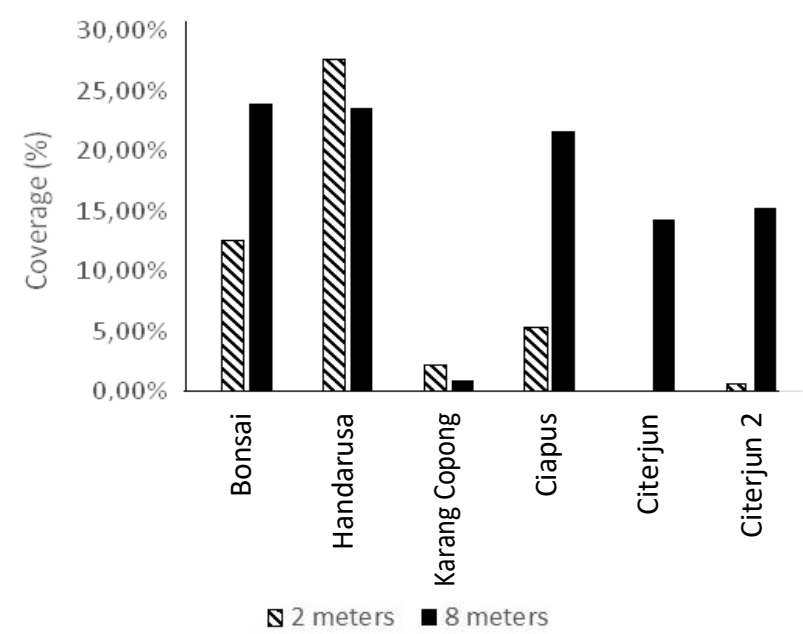

Figure 7. Percentage cover of abiotic (non-living) elements at 2 and 8 meters deep at Peucang Island, Ujung Kulon National Park, Banten, Indonesia 
Visibility in Western and Eastern regions was, between 10-17 meters. The level of visibility indicates that the water still gets good sunlight during daylight. According to Supriharyono, (2007), the coral can grow well at a depth $<20 \mathrm{~m}$, so that more light can still penetrate the water and be good for the coral growth. Visibility from the bottom as far as 10 meters on the sites of Karang Copong and Citerjun, which is presumably because the condition of the research location was in a state of slack tide, resulting sediment particles to get lifted and thus the water looks turbid. Relatively, turbid water conditions can be the trigger for the low percentage of coral coverage as well (Jones et al. 2015).

\section{Condition of reef ecosystem}

The condition of coral reef ecosystem is determined by the amount of hard coral coverage (Manuputty and Djuwariah 2009). Hard coral species commonly found in this study were Acropora Branching (ACB) life-forms. This hard coral life-form can grow in water with strong current, although it can be destroyed if exposed to storms. The atoll has a relatively fast growth rate compared to other types of hard coral. Acropora grows in clean water with high light penetration, free of sedimentation that could impede the penetration of light (Desvianti and Choesin 2015).

The regional management and local fishermen of Peucang Island admitted that many fish bombing activities are used for fisheries, which have caused a lot of damage to coral reefs. As a result, the coral growth rate is not in line with the rate of exploitation. According to Pontoh, (2011), the characteristics of an area affected by fish bombing can be seen when diving in the sea. There is a crater left by the bomb blast and many areas of coral rubble. At the research location, craters from bomb blasts, evidence of coral bleaching and areas of coral rubble was observed at depths of 2 and 8 meters.

In addition, other indicative traits of ecosystem degradation can be seen such as a high percentage of Dead Coral (DC), Rubble (RB), and other organisms such as Soft Coral (SC) (Manuputty and Djuariah 2009). Kilarski and Everson (2008), found that the coral coverage caused by the presence of dead coral fragments (Rubble) and Dead Coral (DC) indicates the process of coral destruction. Severely damaged coral fragments indicate the use of explosives to get the fish on the reefs (Kasnir 2011). Prasetia, (2013), said that if most of coral reef ecosystems are mostly Dead Coral, it stands to reason that the coral reefs have been destroyed. Habitat destruction will impaired food web and impact to fish life.

Dead Coral (DC) is the result of various damage, either from nature itself or humans, which causes the degeneration and loss of the colored zooxanthellae from coral tissue, and the coral won't be able to survive (Yusri 2016). Dead Coral coverage percentage of all locations are included in the category of very high (dead coral coverage> 2\%) (Mellor 2007), with the most severe locations in Karang Copong Bonsai at a depth of 8 meters and 2 meters.

Rubble (RB) including abiotic categories are found in all dive sites, and 7 out of 10 dive sites ( 2 and 8 meters deep) are considered very high because its value of coverage exceeds 10\% (Mellor 2007). Five of the seven locations were found at a depth of 8 meters. This suggests that damage to coral reefs from fish bombing is more prevalent at a depth of 8 meters, with the location of Coral Copong as the location with the most abundant rubble. More coral rubble in the form of fragments would hamper the recruitment of other organisms, and it may take several decades and even centuries for them to recover (Mellor 2007).

Soft Corals (SC) tend to grow more rapidly in areas with low light penetration, which many of them can be found at a depth of 8 meters (Desvianti and Choesin 2015). The existence of soft corals can be used as an indicator of the condition of hard corals and can be a critical state or damaged (Blue and Wijoyo 1999). The location Citerjun at a depth of 8 meters has the highest frequency of the presence of macroalgae. This presumably due to macroalgae which outcompete coral re-growth after disturbance. This is related to the Ciapus site conditions that are categorized as having very high amount of rubble.

Overall, all six areas with a depth of 8 meters in Peucang Island has experienced a higher percentage of damage than those at a depth of 2 meters; this can be seen from the lower percentage cover of hard coral. At a depth of 8 meters, coral reef coverage reaches $26.88 \%$, showing the condition of moderate damage. When compared with data collected in the past three years (Ujung Kulon National Park Authority 2011, unpublished data), coral reef coverage at a depth of 8 meters has decreased by $16.36 \%$. The decrease of coral reef coverage can be a result of by fishing activity. The closer a fishing boat approaches the land, the noisier it will become and hence causing the fish to swim deeper, resulting in a more prevalent of fish bombing (Fauziyah and Jaya 2010).

At a 2-meter depth, the percentage of live hard coral coverage reaches $61.05 \%$, showing good condition and an increase of $14.95 \%$ compared to the data in 2011. Overall, coral coverage on reefs around Peucang Island has experienced moderate damages, with a percentage cover of $43.96 \%$, showed $0.7 \%$ decrease over the past three years (Ujung Kulon National Park Authority 2011, unpublished data).

\section{Community structure of coral reefs}

Diversity Index $\left(\mathrm{H}^{\circ}\right)$ at a depth of 8 meters has an average value of 1.7 , while the value of 1.81 could be found at a depth of 2 meters. According to Princess et al. (2012), both Indexes are classified in the condition with low diversity and community stability $\left(\mathrm{H}^{\prime}<2\right)$. The $\mathrm{H}$ value has decreased compared to coral reefs coverage data of Peucang Island in 2011 with the values of 2.11 (8 metres deep) and 2.25 (2 metres deep) categorised as a moderate state of diversity and community stability $\left(2<\mathrm{H}^{\prime}<3\right.$ ) (Ujung Kulon National Park 2011, unpublished data).

Evenness Index (E) at a depth of 8 meters worth an average of 0.78 , while at a depth of 2 meters, the value is 0.84. Sudiana (2005), said that the Evenness Indices value (E) is close to 1 , which indicates the equal distribution of individuals among species. Evenness Index (E) of Peucang 
Island in this study is more stable than the data in 2011 that worth 0.63 (8 meters deep) and 0.73 (2 meters deep) (Ujung Kulong National Park 2011, unpublished data).

Dominance Indices (C) at 8 meters deep worth an average of 0.25 , while it is 0.22 at a depth of 2 meters. Dominance Index values are nearing 0 which indicate that there are no dominant species (Sudiana 2005). Dominance Index (C) obtained in this study was measured lower than the data in 2011 with the value 0.19 (8 meters depth) and 0.13 (2 meters depth) (Ujung Kulon National Park 2011, unpublished data).

In conclusion, the condition of coral reef coverage in Peucang Island, Ujung Kulon National Park as a whole has experienced moderate damage and decreased coral coverage within three years. Evidence of excessive bomb fishing was present at a depth of 8 meters. The reduction in the value of Diversity Index, Dominance Index as well as Evenness Index in all study sites showed the low diversity of species with no domination. The results also showed that corals are well distributed in both depths. However, exploitation and utilization of natural resources around Pulau Peucang have the potential to increase. Without adequate management and control over the nature of fishing practices in this area, coral reefs will experience continued degradation, leading to damaged marine ecosystems.

\section{ACKNOWLEDGEMENTS}

This study was supported by the Annual Student Program of Natural Exploration of Department Biology Universitas Padjadjaran and Ujung Kulon National Park, Indonesia.

\section{REFERENCES}

Blue ME, Wijoyo NS. 1999. Changes in the great barrier reef conditions Coconut Island, Thousand Islands, Jakarta. Faculty of Fisheries and Marine Resources. Bogor Agricultural Institute; Proceedings of the Workshop and Science and Technology of Coral Reefs Indonesia, Jakarta. [Indonesian]

Burke L, Kathleen R, Mark S, Allison P. 2012. Reefs at risk revisited in the coral triangle. World Resources Institute, Washington SC.

Colwell RK. 2009. Biodiversity: Concept, Patterns, and Measurements. Princeton University, Princeton, New Jersey. www.press.princeton.edu.
Desvianti D, Choesin DN. 2015. Comparison between coral reef ecosystem in the marine tourism zone and core zone in Toyapakeh, Nusa Penida, Bali, Indonesia; Proceedings of the International Conference on Food, Ecological and Life Sciences (FELS-2015), Bangkok, 15-16 June 2015. [Thailand]

Fauziyah J. 2010. Small pelagic fisheries density in acoustics in the Arafura Sea. Sci Res J 13:1.

Hoey AS, Howells E, Johansen JL, Hobbs JPA, Messmer V, McCowan DM, Wilson SK, Prachett MS. 2016. Recent advances in understanding the effects of climates change on coral changes. Diversity 8: 12.

Jokiel PL, Rodgers KS, Brown EK, Kenyon JC, Aeby G, Smith WR, Farrell F. 2015. Comparison of methods used to estimate coral coverage in the Hawaiian Islands. Peer J 3: 954.

Jones R, Browne PB, Fisher R, Klonowski W, Slivkoff M. 2015. Assessing the impacts of sediments from dredging on corals. Mar Pol Bul 102: 19-29.

Kasnir M. 2011. Analysis aspects of marine ecology minawisata governance in Spermonde Islands Pangke District, South Sulawesi. J Mar Sci 16: 61-69.

Kilarski S, Everson A. 2008. Proceedings of the American Samoa coral reef fishery workshop, U.S. Dep. Commerce, NOAA Tech Memo, Utulei, 21-23 October 2008. [USA]

Manuputty AEW, Djuwariah. 2009. Free method point intercept transect to society: baseline studies and monitoring of health reef in marine protected area location. www. coremap.or.id

McCormick MI, Weaver CJ.2012. It pays to be pushy: Intracohort interference competition between two reef fishes. PLoS ONE 7: 8 .

Mellor SM. 2007. A conservation value index to facilitate coral reef evaluation and assessment. [Thesis]. University of Essex, Essex. [United Kingdom]

Odum EP. 1971. Fundamentals of Ecology. WB Saunders Company, Philadelphia.

Papu A. 2011. Coverage condition of Kapoposang Island Reef, Pangkajene Island District, South Sulawesi Province. Sci J Sci 11: 1.

Piquero AS, Delan GG, Rica RLV, Corrales CM, Monte IA. 2015. Coral lifeform structure in selected marine protected areas in Southern Cebu, Philippines. Trop Tech J 19: 2.

Pontoh O. 2011. Fishing with a bomb in the Region Reef Village Arakan and Wawantotulap. J Fish Mar Trop 7: 1.

Prasetia IND. 2013.Type and abundance study of coral recruitment in the coastal village of Kalibukbuk, Singaraja, Bali. J Bu Les 13: 69-78.

Sagar R, Sharma GP. 2012. Measurement of alpha diversity using Simpson index (1/ $\lambda)$ : the jeopardy. En Skep Crit 1: 23-24.

Souter DW, Linden O. 2000. The health and future of coral reefs systems. Ocean Coast Manag 43: 657-688.

Sudiana, N. 2005. Identification of the type and abundance phytoplankton diversity in the Wonokromo Estuary, Porong River Surabaya, East Java. Experience 10: 3.

Supriharyono. 2007. Ecosystem conservation of biological resources. Publisher Reader Student, Semarang.

Ujung Kulon National Park Authority. 2009. National Park Ujung Kulon, Banten. http://www.ujungkulon.org.

Wilsey B, Stirling G. 2007. Species richness and evenness respond in a different manner to propagule density in developing prairie microcosm communities. Plant Ecol 190: 259-273.

Yusri S. 2016. Bleaching coral monitoring. www. terangi.or.id. 